\title{
Sustainable Campus Initiative at Keio University after the Great East Japan Earthquake Disaster
}

\author{
Yingjiu Bai $^{1, *}$, Yasushi Ikeda ${ }^{1}$, Shizuko Ota ${ }^{2}$, and Hikaru Kobayashi ${ }^{1}$ \\ ${ }^{1}$ Graduate School of Media and Governance, Keio University, Kanagawa 252-8520, Japan \\ ${ }^{2}$ Office of Environmental Information, Minister's Secretariat, Ministry of the Environment, Government of Japan, Tokyo 100-8975, Japan
}

\begin{abstract}
After the shock of the Great East Japan Earthquake on 11 March 2011, the issue of local sustainability is presently center stage in the Japanese political process, and educational and research values are imperative for long-term cost savings, risk management, and clean, efficient energy generation. This study illustrates the Sustainable Campus Initiative approach at Keio University that students have been undertaking to make the campus more sustainable and resilient during post-disaster restoration. To unveil innovative recovery concepts, processes, and social challenges, several outcomes that maximize energy efficiency and conservation opportunities are discussed. The results indicate that the Sustainable Campus Initiative contributed to energy relief in the summer of 2011. It made campus life more creative during a period when the 15 percent mandatory power-saving order by the government to big clients of Tokyo and Tohoku Electric was established. Pilot experiments provide a useful example of how the communications media have an extraordinary ability to increase public understanding of social issues. Since the March 11 disaster, power shortages have redirected renewed attention to fossil fuels. As large energy consumers, universities have an increased responsibility to demonstrate their commitment to sustainable design and encourage innovative development concepts in their regions in the future.
\end{abstract}

Keywords Great East Japan Earthquake, disaster recovery, Keio University, peak energy demand reduction, Sustainable Campus Initiative

\section{Introduction}

Currently, sustainability on campus has been woven into operations and planning at some universities around the world, for example at Yale University, the University of Tokyo, University of Cambridge (IARU 2011), and Tsinghua University (Green University Office of Tsinghua University 2012), among others. Campuses are complex systems that require vast amount of resources, careful management of building renovations, and new building construction; they generate significant quantities of waste and have complex utility infrastructure. Thus, in terms of operational needs,

\footnotetext{
* Corresponding author. E-mail: bai@sfc.keio.ac.jp
}

campuses are often likened to cities. Vance and Boss (2012) pointed out that many assessment tools of campus sustainability identified pollution and waste, fossil fuel consumption, and ecosystem preservation as typical problem areas. The success of sustainability comes from the collaboration between students, staff, and faculty on campus. For example, many reports from American universities indicate that the leadership that professors and students demonstrate in environmental, energy, and sustainability issues, which are related to teaching and research, extends to campus management and operations-for instance, MIT's Sustainability Initiatives 2011 (Massachusetts Institute of Technology 2012).

After the March 2011 disaster, power generation in the greater Tokyo area decreased by 20 percent, because the government-mandated cutting occurred in all nuclear power plants throughout Japan. Affected plants operated at 15 percent of capacity in December 2011, and were reduced to zero percent in May 2012. Government-ordered powersaving efforts in eastern and northeastern Japan also have been requested to meet the government's goal. The issue of sustainability at the local scale is now center stage in the Japanese political process, and it reflects how Japanese view economic development and how they live and think about their civic responsibilities.

Japan is well known for its earthquakes, with small earthquakes occurring all the time. Universities often become evacuation centers for neighboring communities during a disaster. The power shortages and the nuclear crisis that followed the March 11 disaster have given a new twist to the concept of a sustainable campus. The Sustainable Campus Initiative not only aims to make campuses more sustainable but also more resilient.

This study has three goals. First, we want to illustrate the Sustainable Campus Initiative new approach that students have undertaken to make the Shonan Fujisawa Campus (SFC) of Keio University more sustainable and resilient during postdisaster restoration. Second, we want to characterize several innovative recovery concepts promoted by green campus activities that reduce peak energy demand and avoid blackouts in the SFC region, now and in the future. Last, we want to discuss the distinct problems that occur when universities have a heightened responsibility to demonstrate 
their commitment to sustainable design and encourage innovative development concepts in their regions, since it is still unclear how to cover peak energy demand in Japan without nuclear power in the summer of 2012.

\section{Keio University Shonan Fujisawa Campus and the Sustainable Campus Initiative}

Keio University is a comprehensive academic enterprise with six major campuses along with a number of affiliated academic institutions located on or near these campuses. In its 150 -year history, Keio University has played a leading role in Japanese society.

The Shonan Fujisawa Campus of Keio University, which opened in 1990 , is located in Fujisawa City $\left(35^{\circ} 20^{\prime} \mathrm{N}\right.$, $139^{\circ} 30^{\prime} \mathrm{E}$ ). As of October 2010, Fujisawa City of Kanagawa Prefecture had a population of 409,657 and covered an area of $69.51 \mathrm{~km}^{2}$ (Figure 1). Currently, SFC consists of the Keio SFC Junior \& High School, three faculties, and two graduate schools. As of May 2011, there were 1220 Junior \& High School students, 4957 undergraduate and graduate students, and greater than 340 faculty members (only permanent member of staffs are included) (Keio University Shonan Fujisawa Campus 2011a).

The mission of SFC is to offer education and research based on an entirely new concept. SFC is a 24-hour campus with its own integrated network environment. All students have laptop computers and can access the campus network system from anywhere at any time. As a part of the Sustainable SFC Initiative, recent surveys on campus life had been carried out from June 2011 to March 2012. Figure 2 shows the personal computer usage time (hours per student) based on questionnaire survey data obtained by the authors from 200 students in July 2011. Based on the same questionnaire survey, the annual electricity consumption of other personal computers is greater than $56,000 \mathrm{~kW} \cdot \mathrm{h}$. In addition, the annual electricity consumption of classroom desktops is greater than $8000 \mathrm{~kW} \cdot \mathrm{h}$.

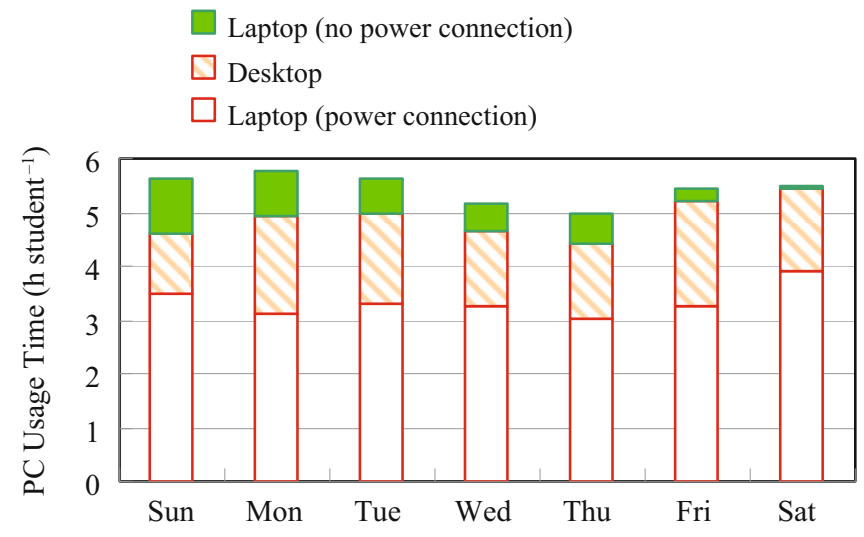

Figure 2. Sample of PC usage time (h student ${ }^{-1}$ ) at Keio University SFC based on questionnaire survey data from 200 students in July 2011

Source: Bai, Ota, and Kobayashi 2011. The surveys as a part of the Sustainable SFC Initiative were carried out by the Ota Laboratory during 6-20 July 2011.

After the March 11 disaster, the university changed the campus time schedule, particularly by shifting many classes from weekdays to weekends in order to reduce peak energy demand and reduce the risk of blackouts in SFC region. Since the government issued a 15 percent mandatory power-saving order to big clients of Tokyo and Tohoku Electric in the summer of 2011, SFC has aligned research and education on sustainability with campus operations to make the SFC region more resilient and achieve greater well-being for the broader community. Figure 3 shows the new concept of campus sustainability initiative at SFC after the earthquake spawned nuclear disaster.

Lessons learnt from Fukushima have been discussed in many universities. Now, reactors in operation were shut down for routine maintenance, only two reactors are online nationwide and both will be offline by May 2012 (The Japan Times 2012a). Japan is confronted with the need for an authentic paradigm shift (Kuhn 1996) toward a truly sustainable, lowcarbon, and nuclear-free energy policy. It is still unclear how

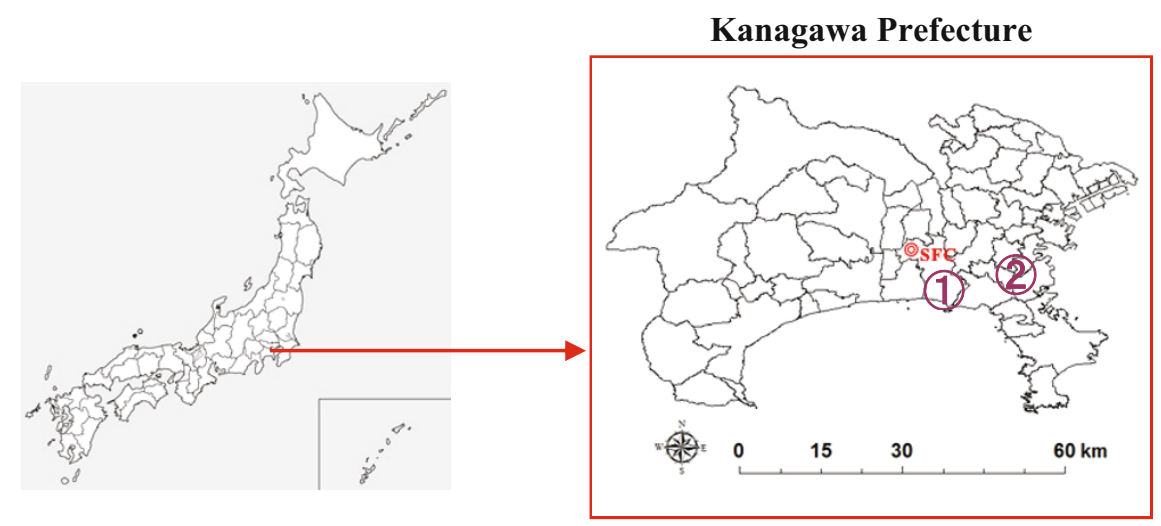

Figure 1. Location of Keio University SFC (1): Fujisawa City, (2): Yokohama City) 
(a)

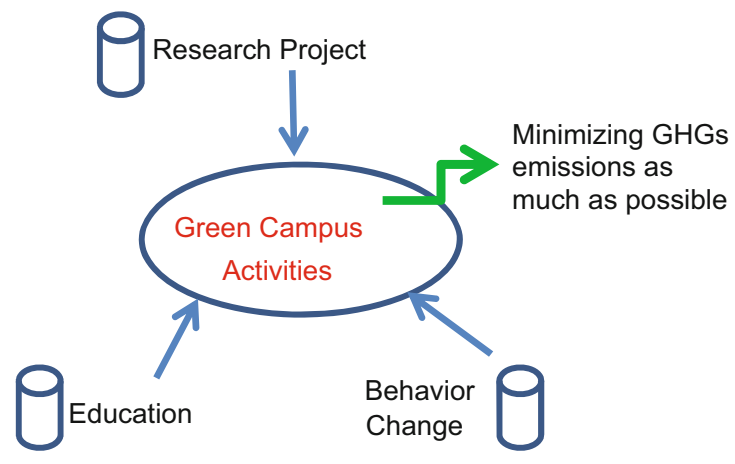

(b)

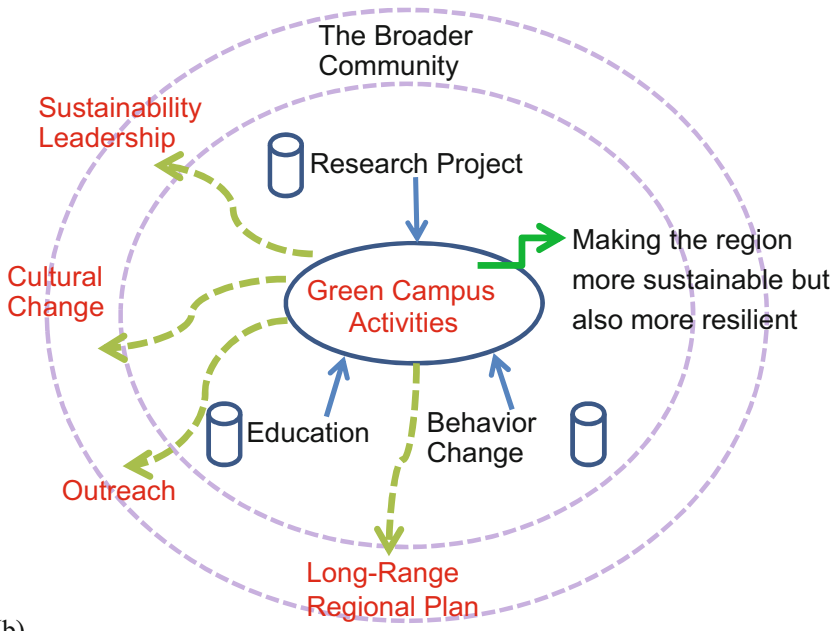

Figure 3. Campus sustainability initiative before the March 11 disaster (a); The new concept of campus sustainability initiative after the disaster in the midst of an energy crisis (b)

to cover peak demand without nuclear power in the summer of 2012 (The Japan Times 2012b), but the Sustainable Campus Initiative approach is valuable as a pilot program to prompt the new energy policy.

\section{Sustainable SFC Initiatives}

The campus energy task force and working groups in SFC recognize that solutions for today's energy challenges will emerge not only from research laboratories and the classroom but also from practice-based innovations and project-based education that focus on reconnecting with the power of nature and reducing power wastage. This can be accomplished through next-generation research, education, and outreach.

To pursue these solutions more strategically, the Sustainable SFC Initiative has established several campus energysaving projects. These projects have transformed SFC to a learning laboratory and a showcase of leading approaches that significantly reduce peak energy demand. Specialized working groups were created in areas of campus energy management, health, transportation, building management, campus environment, and communication. As a part of a long-range campus-wide plan, all projects offer a unique platform for all students, staff, and faculty to develop and implement hands-on behavior change and innovations.

In the past year, Japan has weathered rolling blackouts. In order to avoid blackout and reduce peak demand, power consumption in SFC is visualized using information and communication technology (ICT) and real-time adaptive controls at the SFC Energy-Saving Project homepage (Keio University Shonan Fujisawa Campus 2011b). Now the real-time visualization system of power usage of Keio University has developed on line (Keio University 2011-2012). Furthermore, an innovative real-time analysis system has been developed in order to identify the key actions needed, based on systems analysis, to reduce peak demand every day. This report focuses on only the pilot approach that students have undertaken in 2011 (Keio University Shonan Fujisawa Campus 2011b).

\subsection{New Role for the Media on Campus}

After 11 March 2011, evidence continues to accumulate that Twitter fulfills the task of communication in a disaster and it has become the social network of choice. People change their behavior with this new information and communication technology and new experiences. Currently, in a university setting, Twitter often replaces the formal communication system because information can be quickly processed and is syndicated.

One of the SFC initiatives that students have been undertaking is to make the campus more sustainable through the SFC Energy-Saving Project: Green Curtain Project (GCP 2011) (Keio University Shonan Fujisawa Campus 2011c), which is designed and organized by the students in the Ikeda Laboratory. This undertaking is a project-based student activity and a pilot case study on the use of Twitter in controlling growth of a vegetable, goya, or bitter gourd, a traditional summer vegetable in Okinawa. Maximizing growth potential of goya requires management of the water delivery system and a large number of participants who appear at need to water the plants (goya).

This project aims not only to reduce $\mathrm{CO}_{2}$ emissions and peak energy demand, but also to take a multifaceted approach to conserving energy and develop a better understanding of how to compost a new concept of a green life. For example, a controlled watering system linked to closed environment agriculture is important for growing vegetables but is difficult to manage on a university campus with many people taking part in its use. However, the task of coordination becomes easy and cost-effective when using Twitter as an organizational tool. Twitter is available to keep an open line of communication with all participants at any time, so the students, staff, faculty, and others can participate in the Green Curtain Project activity freely. All participants can upload pictures 
Table 1. Example of how Twitter can help in the water-management system

\begin{tabular}{lll}
\hline Date and Time & Sending Messages or Pictures & Reference for All Participants \\
\hline 10:00, 1 July 2011 & Student A: Weather information and plant & For example, rewatering time \\
16:40, 1 July 2011 & Student B: I watered the plants & Amount of water to give to a plant \\
$17: 40,1$ July 2011 & Student C: I watered the plants & Input the picture of the plant \\
\hline
\end{tabular}

Source: Green Curtain on Twitter. http://twitter.com/\#!/GreenCurtainSFC (in Japanese).

and send messages using the Twitter tool to report goya's growth and the appropriate watering times to promote more rapid growth. As an example, Table 1 shows how the watermanagement system works. The Twitter communication directs project participants to water the plants every day. There are so many participants that vegetables (goya) were well taken care of and grew faster (Figure 4). The goya were harvested in two batches last year.

Figure 4 indicates that the Green Curtain experiment in 2011 was particularly successful because of Twitter. The pilot experiment provides evidence that communications media have an extraordinary ability to increase the public's understanding of social issues and coordinate project participation. But understanding the interaction of multilevel systems in societies and the chain of events in the case of disaster in ecological systems requires both theoretical and applied innovations.

\subsection{New Concept in Campus Power Saving}

The Fukushima nuclear disaster has paved the way for some inevitable changes in the domestic energy policy framework of Japan. During the post-disaster transition period, it is essential that the campus energy and education task forces collaborate to increase energy-related undergraduate research opportunities and assist student-led energy groups and activities. In order to avoid blackout and reduce peak energy demand, many project-based innovative approaches in a new, flexible research building on campus are promoted. The authors' research group offers technical support to challenges encountered in the Sustainable Campus Initiative.

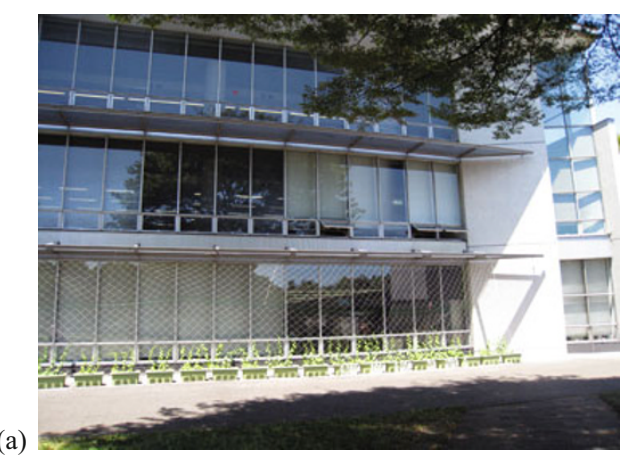

The SFC has its own integrated network environment on campus. All students own laptop computers, enabling them to access the campus network system anytime, anywhere. Figure 5 illustrates the experimental development of a solar-charging unit and the design of outdoor working space as an outdoor research laboratory under the Solar Campus Program at Keio University SFC.

The solar-charging unit is constructed with two foldable solar chargers, two external batteries, and one foldable holder (Table 2). The unit can charge two devices at once, such as a 12 Volt wireless electronics product and an external battery. Because external batteries can automatically adjust to the laptop or netbook's power requirements, the unit is compatible with notebooks, cell phones, smart phones, MP3 players and more (Table 2). The foldable holder is made with rugged, UV-stabilized aluminum alloy materials. The weight of the solar-charging unit is about $10 \mathrm{~kg}$, which is designed to reduce loss or damage from high winds.

As Figure 5 shows, the unit can be rolled up and put away if it rains. It is easily and freely used during rolling blackouts. If a battery is fully charged in the daytime, it can be used in night. This feature helps the university to reduce peak demand, but does not shift class time. This is going to be a revolution not only for power savings but also for creating a disaster-resilient campus.

Additionally, to support the Solar Campus Program's goal of increasing the widespread adoption of solar power technologies, a campus meteorological monitoring system for temperature/humidity data collected every 10 minutes at recording installations was established as a power-saving subproject (Figure 6). These installations are part of a safetymanagement system for the outdoor research laboratory,

(b)

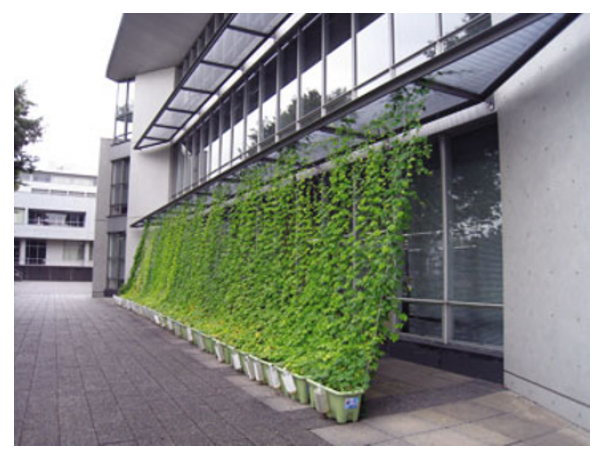

Figure 4. Management using Twitter tool makes vegetables (goya) grow faster

Photographs by Yingjiu Bai, 12 July 2011 (a) and 27 August 2011 (b).

Note: SFC Energy-Saving Project: Green Curtain Project (GCP 2011) was designed and managed by the students in the Ikeda Laboratory from June-October 2011. 
(a)

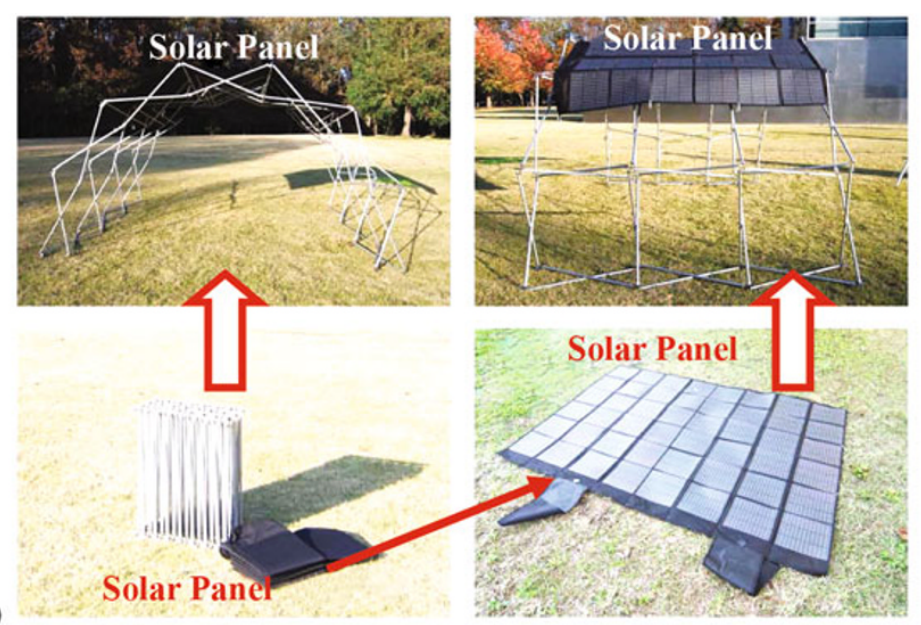

(b)

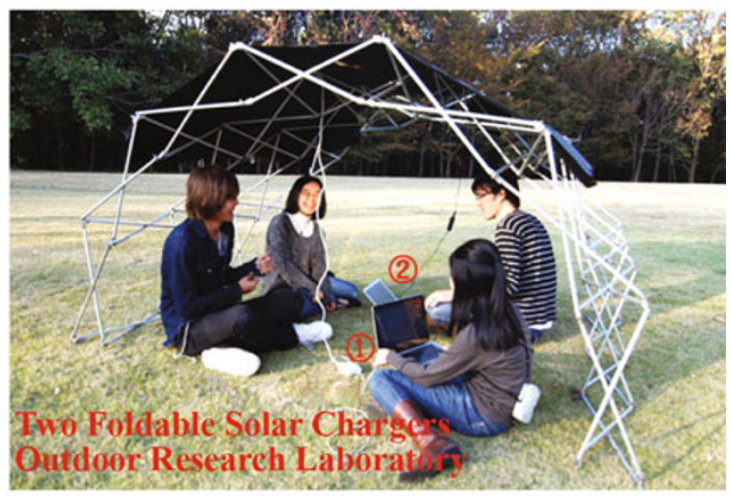

Figure 5. Experimental development of a solar-charging unit (a) and design of outdoor working space as a research laboratory (b)

Photographs by the authors' research group, 27 September 2011.

Note: Mr. Wataru Doi and Mr. Masahiro Sasaki, students in the lkeda Laboratory, designed the outdoor working kits. The last series of experiments with these working kits were conducted by the students in the Ikeda Laboratory from June-October 2011.

Table 2. A solar-charging unit with two foldable solar chargers, two external batteries, and one foldable holder

\begin{tabular}{llll}
\hline & Two Foldable Solar Chargers & Two Batteries & One Foldable Holder \\
\hline Weight $(\mathrm{kg})$ & $1.45 \mathrm{~kg} \times 2$ & $0.51 \mathrm{~kg} \times 2$ & $6.0 \mathrm{~kg}$ \\
& Clear day: & A batter with & Solar panel is face up with orientation to sun \\
Full charge & Fully charge a battery in 2 hours & USB $19 \mathrm{~V}(3.5 \mathrm{~A})$ & (if necessary, move the holder freely) \\
& Cloudy day: & DC 10.5 V (2 A) & External batteries can charge two \\
& Fully charge a battery in 4-6 hours & devices at once. \\
\hline Hour of use & Charge two batteries at once & For laptop: 6 hours \\
& & For cell phone: 112 hours \\
& & For Smartphone: 540 hours \\
& & For camera: 7000 pictures \\
\hline
\end{tabular}

because heat stroke may occur in the summer. Students can choose more comfortable place as their outdoor laboratory based on the data from the campus meteorological monitoring system. The Sustainable Campus Initiative at SFC contributed to energy relief in the summer of 2011 and made the campus life more creative, during a period when the government imposed a 15 percent mandatory power-saving order to big clients of Tokyo and Tohoku Electric.

\section{Discussions and Future Plans}

Nuclear power accounted for about a third of the nation's electricity output before the Fukushima disaster, but plans had been drawn up for reactors to supply some 50 percent of electricity in Japan by fiscal year 2030. After the March 11 disaster, the government had to rethink its energy policy, because the public became well aware of the hazards of nuclear power plants. There is a possibility of rolling blackouts this summer. Discussions about the future direction of the Sustainable Campus Initiative have emerged in campus life. For example, do universities have an increased responsibility to demonstrate their commitment to sustainable design and encourage innovative development concepts in their regions in the future? What distinct responsibilities do institutions of higher learning have in environmental stewardship? As large energy consumers, universities play an important role in their respective regional energy markets and can inevitably influence future decision making.

This study highlights the advantages of a university as a green city relative to more complex systems. The results of field observations in 2011 showcase the potential of the SFC Sustainable Campus Initiative. It is probably safe to conclude that the pilot approach that students undertook in 2011 achieved its predetermined power-saving goals. That success benefits both the goal of reducing the peak energy demand of the campus region and making campus life more creative. 
(a)

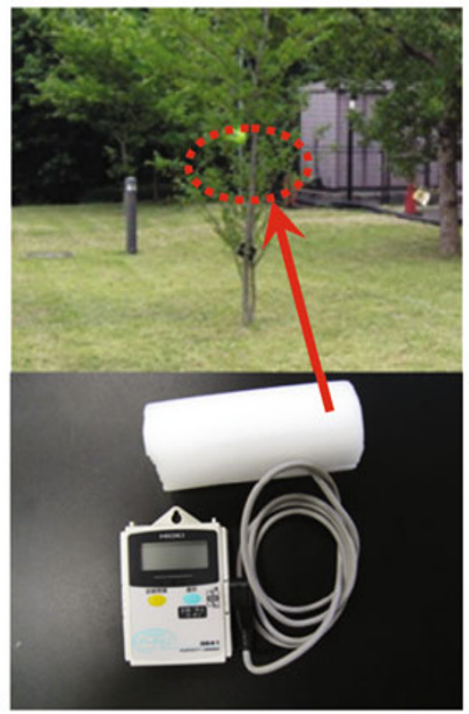

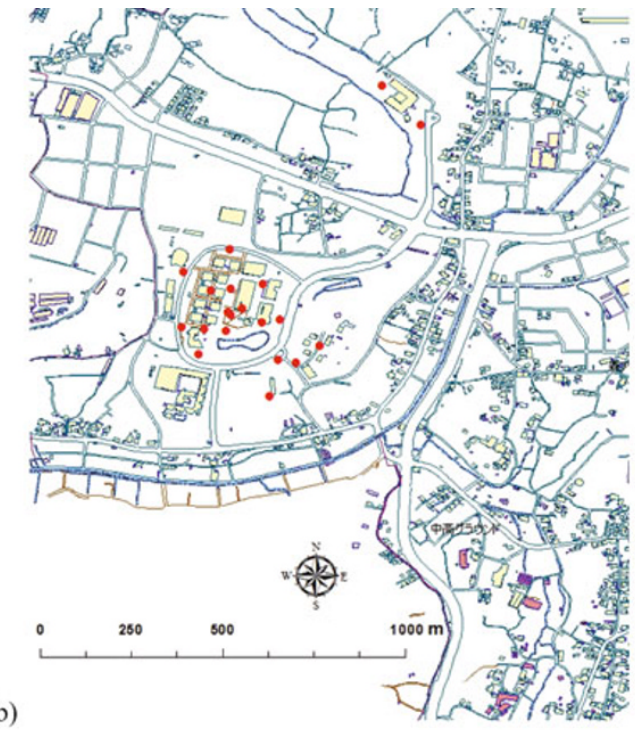

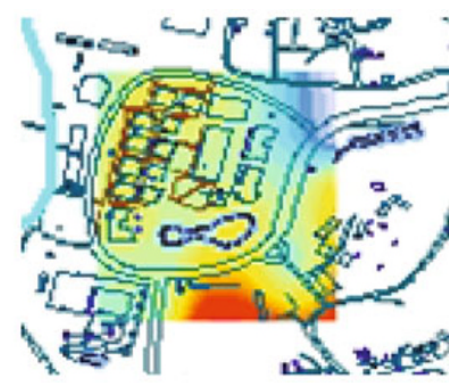

(c)

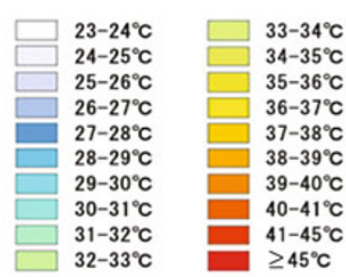

Figure 6. Recording installation with a thermometer placed in a breezy shutter (the sensor is $1.6 \mathrm{~m}$ above the ground) (a); Locations of the meteorological observatories (red dots) selected for this study (b); Air temperature distribution on the SFC campus (mean temperature in August 2011 at 15:00) (c)

(a) Photographs by the authors, 12 July 2011.

(b) and (c) Source: Bai, Ota, and Kobayashi 2011.

There are numerous discussions on Sustainable Campus Initiatives. Henson, Missimer, and Muzzy (2007) state that most such efforts lack a strategy and when a strategy does exist, it often follows from barriers rather than from a long-term goal. The barriers are related to organizational structures, ranging from a lack of top-level commitment, to middle managers' control over decision making, finance and accounting structures, and a quick student turnover, all of which impede sustainable development.

As large energy consumers, universities should focus their green campus activities on environmental sustainability and have a vision for the region and produce an energy roadmap for the coming decades.

Post-disaster power shortages have awakened consumers to the importance of energy efficiency. Moreover, the postdisaster power shortfalls have redirected renewed attention to fossil fuels. So the need to consider the risk of the globally important issue of climate change is acute. As an example, Figure 7 shows that the annual mean temperature (1993-2011) in the SFC region has increased. The warming rate is nearly equal to that in Yokohama City (statistically $1.81^{\circ} \mathrm{C} 100 \mathrm{a}^{-1}$ ), a megacity with a population of 3.70 million (City of Yokohama 2012), covering an area of $434.98 \mathrm{~km}^{2}$ in 2011. Furthermore, the authors' research group has projected monthly mean temperature during the summer season (June, July, and August) in the near future (2015-2039) and beyond (2075-2099) in the SFC region, using a regional climate model with $5-\mathrm{km}$ resolution (MRI-5km). The predicted climate data are based on MRI-5km mesh regional climate model developed by Meteorological Research Institute, Japan Meteorological Agency (JMA) (Sasaki et al. 2012).
The MRI-5km developed by JMA is a dynamical downscaling with a $5-\mathrm{km}$ non-hydrostatic regional climate model that performed to project future changes of rainfall extremes for the summertime using the $20-\mathrm{km}$ mesh model as the initial and lateral boundary conditions (Kitoh et al. 2009). The authors' research group created the downscaled data with a simulation area of $40 \mathrm{~km} \times 35 \mathrm{~km}$, using Geographic Information System (GIS). Figure 8 shows a subset of the latest results of calculation made by the authors' research group. The simulation results by GIS mapping tool indicate that the summer temperature increase rate in the SFC region will be

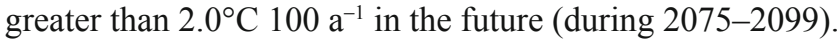

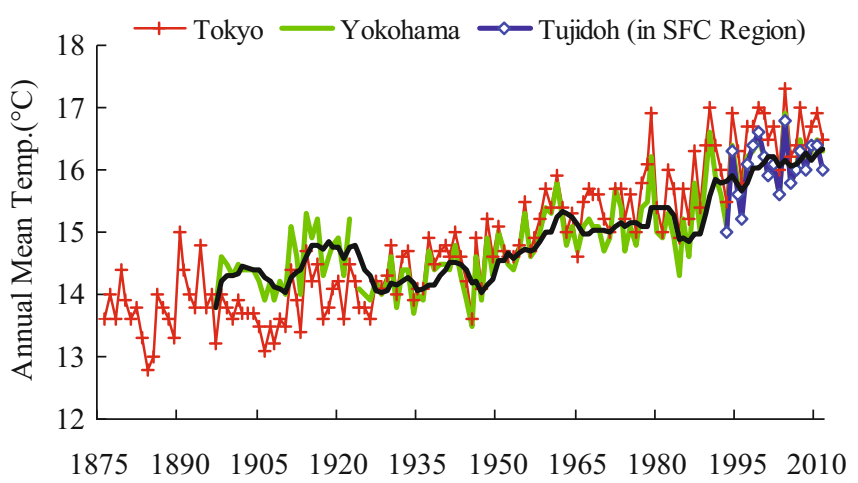

Figure 7. Annual mean temperature increase in the SFC region, Yokohama, and Tokyo

Tokyo Observatory $\left(35^{\circ} 41.1^{\prime} \mathrm{N}, 139^{\circ} 45.6^{\prime} \mathrm{E}\right.$, altitude $=6.1 \mathrm{~m}$ above mean sea level); Yokohama Observatory $\left(35^{\circ} 26.3^{\prime} \mathrm{N}, 139^{\circ} 39.1^{\prime} \mathrm{E}\right.$, altitude $=39.1 \mathrm{~m}$ above mean sea level); Tujidoh Observatory $\left(39^{\circ} 19.2^{\prime} \mathrm{N}, 139^{\circ} 27.0^{\prime} \mathrm{E}\right.$, altitude $=5.0 \mathrm{~m}$ above mean sea level.

Data Source: Japan Meteorological Agency 2012. 


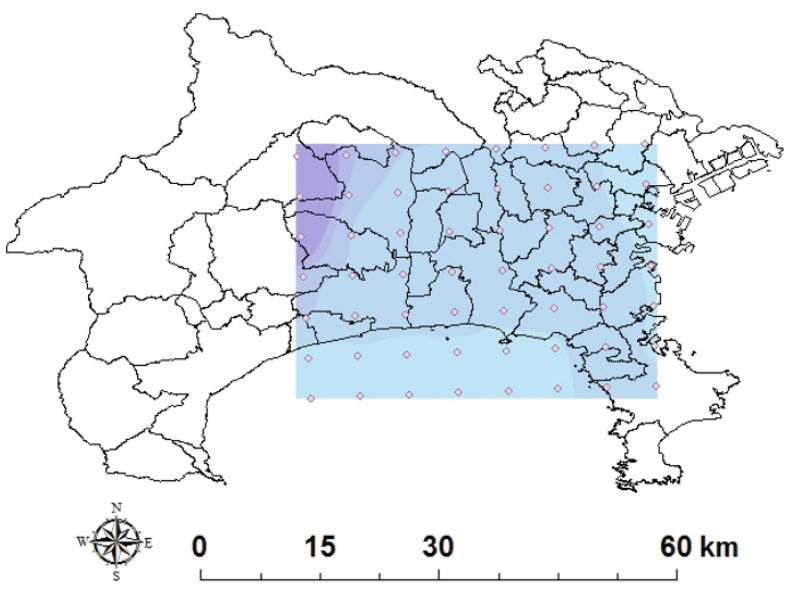

(a)

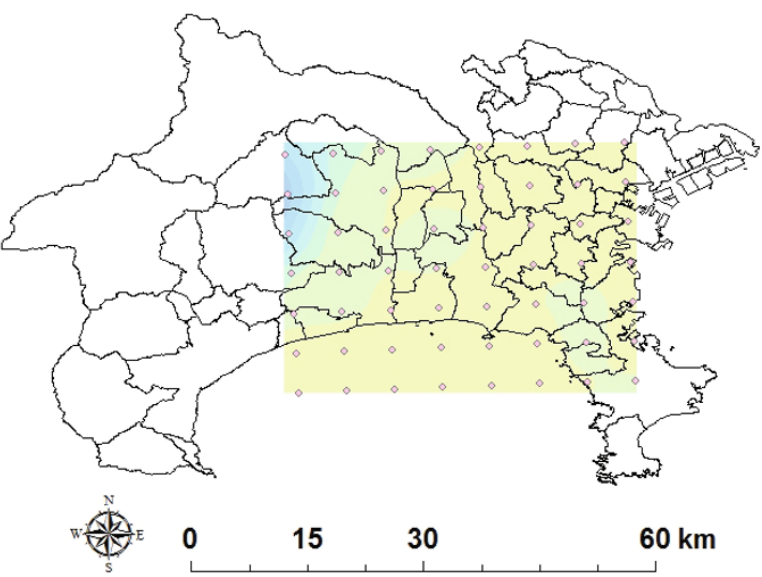

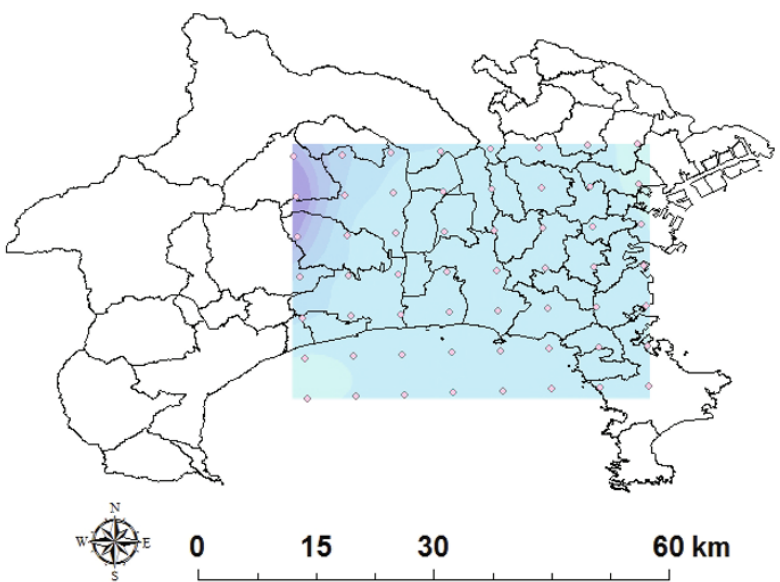

(b)

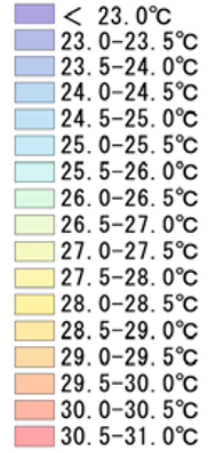

(c)

Figure 8. Simulation of the mean summer temperature (June, July, and August) in the SFC region using GIS: Simulation results for 1979-2003 (a); Simulation results for 2015-2039 (b); and Simulation results for 2075-2099 (c)

Note: The authors created the downscaled data using GIS. The predicted data are based on MRI-5km mesh regional climate model developed by Meteorological Research Institute, Japan Meteorological Agency, a project in the KAKUSHIN Program sponsored by Ministry of the Environment, Government of Japan, 20072012.

The Sustainable Campus Initiative approach has been developed at Keio University SFC, which can potentially meet the challenge to make the campus more sustainable and resilient during the post-disaster restoration process. Furthmore, if the university can align higher education needs and research and campus operation goals to regional long-term sustainable development concerns in a broader framework than simply a response to post-earthquake power shortages, it will contribute to a strategic shift from the country's reliance on fossil fuels to a more sustainable path of growth. It will also have an effect on mitigating local climate change.

The SFC Sustainable Campus Initiative is the beginning of the push toward regional environmental sustainability. In the future, to facilitate consensus-building efforts among communities in the area, it is important to incorporate long-term goals in developing sustainable regional energy plans.

\section{Acknowledgments}

The authors would like to thank the Program to Reform the Social System for the Creation of a New Society Adapting to Climate Change: Green Society ICT Life Infrastructure (Project leader: Professor Ikuyo Kaneko, Graduate School of Media and Governance, Keio University) and the Meteorological Research Institute, Japan Meteorological Agency, for research cooperation and resources supporting this research. In addition, the authors wish to thank all students in the Ota, Kobayashi, Tokuda, and Yan Laboratories for developing the thermal-recorder-observation system and downloading data. The authors are extremely grateful to Mr. Wataru Doi and Mr. Masahiro Sasaki of the Ikeda Laboratory for designing the outdoor working kits. This research has been supported by the Keio University SFC Energy-Saving Project. 
The authors are very grateful to the three anonymous reviewers for their valuable comments, and wish to thank them for their assistance, which helped to improve the quality of this report considerably.

\section{References}

Bai, Y. J., S. Ota, and H. Kobayashi. 2011. Campus Power Saving: The Sustainable SFC Initiative. Presentation at The 2nd Annual Environmental Innovators Symposium in Tokyo: Programs and Actions on Mitigation and Adaptation to Climate Change in Asia and AfricaFrom Post-Disaster Reconstruction to the Creation of Resilient Societies. Keio University, Tokyo. December 2011. http://ei.sfc.keio. ac.jp/images/stories/ei/symposium2011/s3 7 bai.pdf.

City of Yokohama. 2012. Population News $\bar{N}$ o. 1030. http://www.city. yokohama.lg.jp/ex/stat/jinko/news-e.html.

Green University Office of Tsinghua University. 2012. Tsinghua's Experience of Building Green University. http://gu.cic.tsinghua.edu. $\mathrm{cn} /$ article3310.shtml.

Henson, M., M. Missimer, and S. Muzzy. 2007. The Campus Sustainability Movement: A Strategic Perspective. Master's thesis, School of Engineering, Blekinge Institute of Technology, Karlskrona, Sweden. http://www.bth.se/fou/cuppsats.nsf/all/b0f8e324039811c4c12572f 200781f69/\$file/CSMthesis_MH_MM_SM.pdf.

IARU (International Alliance of Research Universities). 2011. Brief Summary-IARU Member Reports from Campus Sustainability Report for Presidents' Meeting 2011. http://www.iaruni.org/images/ stories/Sustainable Campus Report - PM2011.pdf.

Japan Meteorological Agency. 2012. Metrological Data (1875-2012). http://www.data.jma.go.jp/obd/stats/etrn/select/prefecture00.php? prec_no $=\&$ prec_ch $=\&$ block_no $=\& b l o c k \_c h=\& y e a r=\&$ month $=\&$ day $=\& \bar{e}^{-} \mathrm{m}=\& \mathrm{view}=($ in Japanese $)$.
The Japan Times. 2012a. Summer Power Crunch Looms Large. Saturday, 10 March 2012. http://www.japantimes.co.jp/text/nn20120310f1. html.

. 2012b. Japan Nuke-Free for First Time Since '70. Sunday, 6 May 2012. http://www.japantimes.co.jp/text/nn20120506a1.html.

Keio University. 2011-2012. The Real-Time Visualization System of Campus Power Usage. http://setsuden.keio.ac.jp/chartp/power_all. html (in Japanese).

Keio University Shonan Fujisawa Campus. 2011a. Students, Faculty, Graduates. http://www.sfc.keio.ac.jp/about_sfc/facts/number.html (in Japanese).

. 2011b. SFC Energy-Saving Project. http://setuden.sfc.keio.ac. $\mathrm{jp} /$ (in Japanese).

. 2011c. SFC Energy-Saving Project: Green Curtain Project (GCP 2011). http://setuden.sfc.keio.ac.jp/gcp/gcp.html (in Japanese).

Kitoh, A., T. Ose, K. Kurihara, S. Kusunoki, M. Sugi, and KAKUSHIN Team-3 Modeling Group. 2009. Projection of Changes in future Weather Extremes Using Super-High-Resolution Global and Regional Atmospheric Models in the KAKUSHIN Program: Results of Preliminary Experiments. Hydrological Research Letters 3: 49-53. https://www.jstage.jst.go.jp/article/hrl/3/0/3_0_49/_pdf.

Kuhn, T. S. 1996. The Structure of Scientific Revolutions. Chicago: University of Chicago Press.

Massachusetts Institute of Technology. 2012. MIT Energy Initiative. http://web.mit.edu/mitei/research/index.html.

Sasaki, H., A. Murata, M. Hanafusa, M. Ohizumi, and K. Kurihara. 2012. Projection of Future Climate Change in a Non-Hydrostatic Regional Climate Model Nested within an Atmospheric General Circulation Model. SOLA 8: 53-56. https://www.jstage.jst.go.jp/ article/sola/8/0/8 2012-014/ pdf.

Vance, L., and S. K. Boss. 2012. The Campus Demotechnic Index: A Comparison of Technological Energy Consumption at US Colleges and Universities. http://www.citeulike.org/article/9573586.

Open Access This article is distributed under the terms of the Creative Commons Attribution License which permits any use, distribution, and reproduction in any medium, provided the original author(s) and source are credited. 